\title{
Viability planning, value capture and the geographies of market-led planning reform in England
}

\author{
Jessica Ferm and Mike Raco
}

Bartlett School of Planning, University College London, London, United Kingdom

Central House, 14 Upper Woburn Place, London WC1H 0NN

Email: j.ferm@ucl.ac.uk

Jessica Ferm is Lecturer in Planning and Urban Management and Director of Undergraduate Programmes at the Bartlett School of Planning. She is a practice-focused academic with research interests in spatial planning, economic development and social justice and has published widely on these topics in Urban Studies, European Planning Studies, Planning Practice and Research, Journal of Corporate Real Estate. She is co-editor of a book on Planning Practice in the UK, (Routledge, 2018) and co-author of Understanding the Impacts of Deregulation in Planning: Turning offices into homes (Palgrave Macmillan, 2019). She has worked on research projects for the RICS Research Trust and the Ministry of Housing, Communities and Local Government. Jessica is active in planning practice and policy in London. Prior to becoming a lecturer, Jessica worked for ten years as a planning consultant and in public practice for a north London planning authority.

Mike Raco is Professor of Urban Governance and Development and Director of Research in the Bartlett School of Planning. His background is in Planning, Geography, and Urban Studies. He has published widely on the topics of urban governance and regeneration, urban sustainability, social diversity, and the politics of urban and regional economic development. He is currently leading an ORA/ESRC funded international comparative research project named WHIG? looking at the relationship between residential investment flows and regulation in London, Paris and Amsterdam. Recent works include: The Future of Sustainable Cities: Critical Reflections (with John Flint, Policy Press, Bristol); State-led Privatisation and the Demise of the Democratic State: Welfare Reform and Localism in an Era of Regulatory Capitalism (Routledge, London); and Regenerating London: Governance, Sustainability and Community in a Global City (with Rob Imrie and Loretta Lees, Routledge, London). He formerly lectured at King's College London and the Universities of Reading and Glasgow. 


\begin{abstract}
This paper focuses on the contentious transition to viability-driven planning in England, whereby development viability and the potential for land value capture dominate the work of planning. Drawing on interviews and fieldwork in London and the north east of England, the paper reflects on the variable outcomes and challenges in places with different development markets, political cultures, development histories and capacities for action. It finds that viability-driven planning is further entrenching already existing spatial disparities and inequalities and draws conclusions about the state of English urban policy in the context of a broader shift towards the marketisation of planning.
\end{abstract}

Keywords: viability; planning; England; marketisation; urban policy; land value capture; development

\title{
Introduction
}

Since 2010 the English planning system and urban and spatial policy programmes have undergone further rounds of reform and evolution (Ferm \& Tomaney, 2018). Traditions of area-based initiatives and community-focused planning have given way to an intensification and re-tooling of market-led arrangements, underpinned by a combination of viability-driven private sector-led delivery and the implementation of locally negotiated, but centrally directed, value-capture mechanisms. The rise to prominence of what we term viability-driven planning [VP] is embedded in a broader shift towards the marketisation of planning, which as Penny (2017) argues, has intensified since the financial crisis and has parallels with US models of localism and growth regimes. Central to these changes is the reorganisation of local government finance, under a reformed 
centralised localism, requiring greater self-sufficiency on the part of local authorities through the local retention of growth-dependent taxes such as business rates (Raco, 2018). It is an approach that privileges growth over other concerns and locks planning authorities into a dependence on property market uplift - and thereby private sector actors - to deliver basic services and facilities. This shift is being further exacerbated by austerity-driven local government budget cuts of 49.1\% in real terms between 2011-2018, unprecedented in the post-war era (National Audit Office, 2019). The purpose of reform is to convert the inherent messiness of places into ordered investment spaces to re-make planning into a vehicle for public revenue-generation and expedited private investment.

Whilst earlier research identified variability associated with local planning gain agreements and highlighted the importance of local government capacities in shaping outcomes (see Campbell et al., 2000), there has been less research on the geographically varied contexts that shape post-2010 reforms, and the impacts of reform on local planning politics and contexts, beyond studies that highlight quantitative evidence of pathdependencies in developer contributions (Dunning et al, 2019) and the longer-term evolution of planning gain as a form of political economy (Catney \& Henneberry, 2019). There is also a body of research on development viability, led by academics who understand and wish to examine the detail of viability calculations, and the assumptions therein (for example Crosby \& Wyatt, 2016; Crosby et al., 2010, 2013; McAllister, 2017). Some of this research has had a direct influence on Government policy and guidance developed by the Royal Institute of Chartered Surveyors but does not explore the complex process of evolution and place-embeddedness in which viability-driven approaches are rolled-out in highly variegated circumstances and environments. The paper bridges these gaps and outlines some of the broader conceptual framings that explain the rise of VP and 
its spatial variability, turning to the question of what this means for the nature and purpose of the planning system and English urban policy.

The English case is particularly salient as market-led reforms to the planning system have gone further and deeper than in any other comparable European country. Despite this exceptionalism, it presents an instructive example of a wider policy trend, with policymakers in a variety of national contexts looking to market-led, value-capture mechanisms as a platform for modernising planning (see Raco \& Savini, 2019). Supranational agencies, such as the World Bank, are pushing for local and national governments to entrepreneurialise their planning systems and limit direct forms of spatial intervention (Amirtahmasebi et al., 2019), even in countries such as the Netherlands where redistributive planning policies have traditionally been effective (Van der Krabben \& Jacobs, 2013). English reforms lack consideration for local and regional place-based nuances (McGuinness et al., 2018), reflecting broader international trends in which 'place-neutral' approaches are gaining traction over 'area-focused' initiatives (Barca, 2009).

In this paper, we draw on in-depth qualitative research in English local planning authorities to examine the 'work that viability does' as a mode of market-led governance reform, how it is re-shaping central-local state relations, and the conditions that shape its geographical variability and influence on local practices and development politics. Whilst the integration of viability appraisals in planning seeks to externalise qualitative values from local decision-making, the paper explores some of the local responses and challenges that are emerging in different contexts and the geographical conditions and circumstances that shape and influence the impacts of VP on places. We show how its 
entrenchment in national policy, coinciding with austerity cuts, represents a different phase in English planning that is leading to uneven spatial outcomes and - as with all market-led forms of intervention - is further entrenching already existing spatial disparities and inequalities. Perhaps most significantly, we argue that a stronger geographical focus draws attention to the under-discussed disappearance of area-based initiatives and the implications for different communities and place economies. English urban policy has existed since the instrument of the Urban Programme was introduced in 1968 and included area-based initiatives of international significance, including Urban Development Corporations and the New Deal for Communities (Edwards \& Imrie, 2015). The implications of an entrenched viability-led approach to planning for the future of urban policy in England are explored as a key theme in the paper.

In the next section we begin by charting the rise of VP in the English system, and dominant academic reflections on the process. We then highlight the implications for understandings of planning as a mode of governance, before turning to our empirical analysis based on in-depth interviews with planners and policy analysis in a sample of urban English local authorities.

\section{The rise of market-led viability planning and the reform of English urban policy}

\section{The implementation and evolution of viability planning}

The inclusion of financial viability criteria in planning policy and decision making emerged in an incremental, ad-hoc manner from the late 1990s, but the extent to which 
English planning is now driven explicitly by viability concerns is unprecedented. (McAllister, 2017). Their rise to prominence represents an evolution of earlier rounds of post-war planning legislation, which used the public allocation of development rights to raise funds from developers and boost spending on public infrastructure through valuecapture mechanisms of 'planning gain', or what was previously termed 'betterment' (Campbell et al., 2000). As Catney and Henneberry (2019) demonstrate, during different eras of post-war economic governance in England, value-capture mechanisms took on important roles in legitimating the planning system as a form of effective state intervention. In the post-war decades they acted as policy instruments to exert control over private development practices and share the gains of development more evenly between individuals, firms and the welfare state. During the Thatcher and Major eras (1979-1997), planning gain became institutionalised as an 'acceptable' form of state intervention to legitimise property development and generate certainty for private investors (Booth, 2003; Healey, et al, 1995). In the New Labour era (1997-2010) they played an important symbolic role by demonstrating how public policy interventions could both generate economic growth and provide an institutional vehicle for the provision of public goods.

Campbell and Henneberry (2005) illustrate the divergent views and experiences of professional planners working during the New Labour era, revealing the dilemmas they faced working within an increasingly market-oriented planning system, with many resisting pressures to take into account development viability in their negotiations. What characterises the most recent shift to $\mathrm{VP}$ is the requirement for planners to consider viability in drafting policies, not just in post-application development negotiations. The catalyst was the need to demonstrate the feasibility of the ambitious $50 \%$ affordable 
housing target in the 2004 London Plan, set by the then Labour Mayor, Ken Livingstone (Christophers, 2014). Subsequently, the rationale for widespread adoption in policy coincided with a broader national post-financial crisis project to boost housing supply and promote development stalled by the burden of planning obligations imposed on developers (Crook, 2020).

The most significant incremental development was the adoption in 2012 of the National Planning Policy Framework (NPPF) in which a focus on viability was institutionalised and rolled-out across the country ${ }^{1}$. Although many planners working in practice had long considered a working knowledge of development appraisals and financial viability to be critical to effective negotiations with developers (Campbell \& Henneberry, 2005), the emphasis in the NPPF suggested that viability should now be a core planning concern and that the role of planners is not only to be mindful of market realism in their negotiations but to facilitate the delivery of landowners' and developers' profit. Subsequent Viability Planning Practice Guidance (DCLG, 2014) was published, which emphasised the importance of conducting viability assessments at the plan-making stage, so that the cumulative impact of policies did not risk their implementation and to facilitate development throughout the economic cycle. The guidance went as far as to say that 'decision-taking on individual applications does not normally require consideration of viability' (para 016). The focus of reform has been to use viability-based negotiations and mechanisms to re-characterise 'planning gain' as a vehicle to facilitate urban development projects, rather than acting as a barrier to intervention or a perceived

\footnotetext{
${ }^{1}$ As stated in paragraph 173 (DCLG, 2012) 'the sites and scale of development identified in [local] plans should not be subject to such a scale of obligations and policy burdens that their ability to be developed viably is threatened. To ensure viability, the costs of any requirements for affordable housing, standards, infrastructure contributions or other requirements should, when taking into account of the normal cost of development and mitigation, provide competitive returns to a willing land owner and willing developer to enable development to be deliverable.
} 
negative 'obligation'. It enables private actors to 'cost-in' their planning gain commitments through viability calculations, thereby removing the pre-existing perception of such arrangements as a post-development cost or form of taxation to support local authority budgets (Bailey, 1994; Dunning et al., 2019).

In practice, however, the years following 2012 saw increased use of viability appraisals by the private sector in negotiations on planning applications, which led to a dramatic reduction in affordable housing delivery and a failure to capture the sought-after planning 'gains' that were promised (Grayston, 2017). A growing anti-viability politics emerged, with developers accused of exploiting planning authorities and avoiding the delivery of affordable housing (Pidd \& Cocksedge, 2018). The House of Lords' (2016) Select Committee on National Policy in the Built Environment 'heard evidence that viability is...now the key element in discussions between local authorities and developers over specific planning proposals' and that 'the absence of an agreed methodology means authorities approach the issue differently, causing uncertainty and delay as well as the potential for exploitation by developers seeking to avoid planning obligations' (paragraph 325). One London authority, providing evidence to the Committee, explained the problem of 'circularity' in the calculation of land cost in viability assessments, whereby:

'developers will bid for land on the basis of their ability to avoid planning obligations, with the bidder who is the most confident about avoiding the costs of such obligations bidding the most. This inflated land cost is then factored into developers' viability assessments and used in itself as justification for avoiding planning obligations' (paragraph 312). 
The Committee concluded there was compelling evidence that the consequence of these provisions in the NPPF was to undermine the delivery of affordable housing and other planning objectives. In addition, the Government has expressed concern about the expanding use of viability assessments in planning permission negotiations, which was delaying the planning process and 'causing complexity, uncertainty and increased risk for developers' (para 27, MHCLG, 2018a).

Academic experts on financial viability have argued that development appraisals have intrinsic uncertainty, and clear incentives for developers, landowners and their consultants to bias calculations (McAllister, 2017; Crosby et al., 2010). Others have interrogated the methods for (and assumptions made in) assessing appropriate returns to the developer, landowner and community (Crosby \& Wyatt, 2016), how land value should be calculated (see Coleman et al., 2012), or more broadly questioned the technical suitability of using the development viability modelling process in policy making within the UK planning system (Crosby et al., 2013). Yet, as Christophers (2014, p.88) points out, the debate has not focused on 'the appropriateness of using calculative models...but merely the level and kind of possible future refinements to the model which has already been built'. Reflecting this lack of fundamental critique, the revised NPPF and associated guidance (MHCLG, 2019, 2018b) reinforces the viability-driven approach, whilst addressing some of the technical weaknesses and loopholes associated with the original. The implications go beyond the specific circumstances in which the policy has been introduced, reflecting and reproducing a broader, and potentially much more significant transformation, in how spatial planning is understood and given purpose - a topic we turn to in the next section. 
New Forms of Centralised Localism and the Spatial Effects of Viability-Driven

\section{Planning}

Viability-driven planning reflects the latest incarnation of a centrally directed localism that requires local planners, citizens, politicians and communities to consider how the planning of places can be re-shaped to address national policy priorities for the increased delivery of housing units and infrastructure. Rather than directing growth strategically from the centre, or through regional structures, the emphasis is placed on local actors and their capacities to generate entrepreneurial forms of development-led planning. This, it is imagined, will stimulate growth in areas of need, whilst capturing the uplift in market values to meet growing welfare budget demands. It is assumed that the promotion of market-led planning will incentivise local authorities in all contexts to give more weight to the adoption of 'boosterist' approaches to development, with investment attracted to those places with the most developer-friendly authorities. It is an approach that seeks to use financial instruments to tackle the limitations of earlier rounds of localist reform in the 1980s and 1990s, that also encouraged local governments to adopt more developmentfocused policies but gave them few financial incentives to do so (Eisenschitz \& Gough, 1993). It has close parallels with historically-embedded systems of land and development taxation in the United States and the much-documented analysis of urban regimes, growth-machines, and boosterist local economic development policies (Cox, 1993; Savitch et al., 2002). English local authorities depend on development tax revenues to a greater extent than found in most European systems in which there is greater central state redistribution of funds ${ }^{2}$.

\footnotetext{
2 Jenkins (2020) notes that local government in England now controls budgets for its spending equivalent to only $1.6 \%$ of GDP... against $6 \%$ in Germany, $12 \%$ in France and $15 \%$ in Sweden.
} 
Yet within these agendas there is little reflection on how the promotion of marketled planning may reinforce uneven development rather than helping to rebalance spatial economies. Property and investment markets are highly diverse and segmented and since the 1980 s there has been a marked concentration in areas of high market potential and return, at the expense of more peripheral places (Hildreth \& Bailey, 2014). For McGuinness et al. (2018) the reliance on market processes derives from both a 'lack of place-based (spatial) sensitivity in the English planning system' and a selective spatial imaginary that desires 'to accelerate land supply in dynamic housing markets in southern England, where pressure on land, problems of housing affordability and opposition to development are intense' (p.330). The implications, they argue, for places where property and land markets are weaker, have not been considered in the formulation of policy, beyond the vague justifications set out above that imagine that place economies will rebalance over time. It is an approach that fails to recognise that, as Jessop (2003) argues, 'much of what passes as market failure' - such as the emergence of uneven spatial development - is 'actually an expression of the underlying contradictions of capitalism' that are likely to be reinforced by the entrenchment of VP (p.14).

What is less widely discussed are the impacts of this commodification of places in areas with high or low market potential and whether recent reforms are entrenching inequalities or bringing into being more dynamic forms of planning and economic growth in 'laggard' areas. Since the late 1970s successive governments have used a range of planning instruments and interventions to acquire and prepare land for development in places in which there is relatively little market interest (Edwards \& Imrie, 2015). Estateled regeneration programmes and area-based initiatives attempted to tackle the complex array of place-based social and economic problems found in areas of deprivation, albeit 
with indifferent results. It was an approach that required the long-term commitment of financial resources and political will and an acceptance that it may take many years to create viable local development markets. As noted above, the re-tooling of viabilitydriven approaches has prioritised interventions that generate higher market returns, with permissions increasingly divorced from longer-term strategic considerations. It is inherently focused on short-term, site-by-site negotiations, rather than the longer-term impacts of new developments on places. What this means for local development planning in places that have traditionally been in receipt of state investment has yet to be systematically assessed.

It is not only market conditions that differ geographically. As earlier research on betterment and planning gain has shown, both in England and in other European countries in which similar schemes exist, there is significant geographical variation in the take-up of available mechanisms reflecting differing capacities and political buy-in by local governments (Campbell et al., 2000). As Askew's (2018) comparative work demonstrates, the English planning system is uniquely centralised as 'instruments are created by central government and apply to the whole country...[along with] the centralisation of planning regulations that have to be adhered to by planning authorities; local regulations cannot be made' (p.87). Whilst local plans are produced, they are not legally-binding, meaning that the system is reactive to specific applications from private interests, who are more likely to respond to price and market signals, rather than the meeting of public policy objectives.

Contemporary viability-led reforms in England are being introduced into places that possess very different political cultures, development histories and capacities of 
action, where local actors are having to implement central government viability instruments, whilst taking account of a variety of local political demands. When confronted with viability-driven negotiations planners, policymakers, and citizens are therefore required to engage in highly politicised processes of commensuration, that is to convert complex, place-centred policy demands into quantifiable, calculable and numerical units of 'market viability' (Espeland \& Stevens, 1998). It is in these processes of commensuration that planners and other local interests may be able to introduce varied axiological framings into planning negotiations, with different degrees of 'value' given to geographically diverse priorities and measures, adding further to the geographical variability of reform processes (Miller, 2008). The re-focusing of local planning and development politics through governance technologies of 'viability' means, in turn, that qualitative demands and concerns have to be made numerically calculable, and as Déjean et al. (2004) note, all processes of 'quantification involve the reduction of an object to subsets of elements that can be standardised and quantified. This results in abandoning an object's dimensions that cannot pass the test of quantification. Measure means a loss of information and it reshapes the notion to some degree' (p.744) (see also Giamporcaro and Gond, 2016). And, as Morphet and Clifford (2017) show, local authorities across England have developed a range of responses to austerity cuts, including the creation of new ventures and innovative policy responses in their attempts to bridge the gaps between national policy objectives and local planning priorities. It is therefore likely that the manifestation of VP will be varied according to how it is interpreted, understood, performed and implemented in different places facing different political and economic challenges. 
The remainder of the paper turns to our research findings and addresses these broader themes and research gaps. We draw on in-depth, face-to-face, semi-structured interviews with eight representatives of national, metropolitan and local planning agencies, as well as observational work and documentary analysis undertaken during 2018-19. The fieldwork coincided with the consultation on, and subsequent publication of, the revised NPPF, as well as the Examination in Public on the new London Plan held between January and May 2019. Our research therefore included a review of the 2012 and 2018 NPPFs and interviews with two civil servants in the Ministry of Housing, Communities and Local Government (MHCLG) who were directly involved in the writing of the two frameworks. We attended and observed the Examination session on the viability of the new London Plan, as well as reviewing and analysing written representations from various interest groups submitted to the Planning Inspector overseeing the Examination. Finally, we interviewed, and sought to contrast the views of planners and senior local authority officials working in (a) different areas of London (inner and outer London), representing different land and housing markets within the capital, and (b) two cities within a peripheral post-industrial region in the North East of England, again with different local markets, building on the earlier work of McGuinness et al. (2018). With consent, interviews were recorded, transcribed and analysed thematically. More specific information regarding our interviewees has been excluded in order to preserve anonymity. A summary of the key characteristics of the locations where we conducted our interviews is provided in Table 1.

\begin{tabular}{|l|l|l|l|l|}
\hline Location & Average house & Occupational & Workless & Political leadership \\
& price (Jul 2018 & profile: & households & \\
& -July 2019) & Professional & $(\%)$ & \\
\hline
\end{tabular}




\begin{tabular}{|l|l|l|l|l|}
\hline & & and managerial & & \\
\hline Inner London & $£, 761,742$ & 71.7 & 15.9 & Labour (since 2013) \\
\hline $\begin{array}{l}\text { Outer London } \\
\text { borough }\end{array}$ & $£ 424,395$ & 49.6 & 11.7 & Liberal Democrats \\
\hline $\begin{array}{l}\text { NE England } \\
\text { (Newcastle) }\end{array}$ & $£ 204,213$ & 49.1 & 19.9 & Labour (since 2011) \\
\hline $\begin{array}{l}\text { NE England } \\
\text { (Middlesbrough) }\end{array}$ & $£ 149,311$ & 32.3 & & \\
\hline
\end{tabular}

Table 1: Key characteristics of the interview locations (Sources: Zoopla, ONS Annual Population Survey)

The discussion is divided into two sections: first we examine the impact that segmented and highly variable local property markets have on the rolling out of VP; and second, we assess the politically varied conditions that shape local government responses to viability and the types (and extent) of 'local entrepreneurialism' that are emerging in different places.

The spatiality and local development politics of viability planning

\section{Diverse markets and emerging geographies of viability}


The most significant factor shaping the spatiality of VP was that of diverse market potential. As noted in Table 1, our case study locations show market divergence in relation to house prices and labour markets. In this section we draw the findings together under two principal areas of discussion.

First, despite the intention to use viability-framed negotiations to de-politicise place-based local planning politics, its introduction has helped to energise longer-term latent political debates over the location and delivery of new housing. It has provided developers with new political leverage to push for the opening up of sites with highest market returns. In Newcastle, for instance, the City Council has facilitated house-builders to build on sites in the green belt, in ways that overcome long-term political resistance. Our interviewees noted that local politicians had been converted to being pro-greenfield development in the wake of budget cuts, the pressure to yield to delivery targets, and the perceived potential of viability-driven planning gain agreements to facilitate new investment. As one officer recalled in relation to a major development by one of the UK's biggest house-builders,

to open up a site they [the house-builder] have to spend in excess of $£ 10$ million. They need to give us land for primary and secondary schools and pay for it. So they need certainty they can build, say 1200 houses, even though they were originally allocated 800 . And we are going to have to accept that trade-off.

Within such environments there is political pressure to prioritise quantitative abstractions of growth, whatever its quality and/or broader impacts on local built environments, infrastructure and communities. The prospects for the development of former industrial 
sites found within such cities are declining further as they are viewed as 'un-viable' in market terms and large house-builders and investors become the only actors with the market power and resources to bring projects into being. As an interviewee in Newcastle noted, the implications for spatial planning were potentially enormous: "How do I get housing delivered away from the green belt? Everything in most areas of the city is not viable".

In such contexts the urgent need to deliver economic development and housing targets made local authorities dependent on private resources and finance for new development, but weak markets meant that the imposition of planning obligations and social value became "almost aspirational". In the words of a planner in Middlesbrough, "It is hard to be over-assertive. People [private companies] know your weaknesses and vulnerabilities. They know we are desperate for development". Staff shortages, exacerbated by austerity, further weaken the position of planners in such authorities: "We have few staff and don't want to do 'little' building projects or deal with small plots, so we now allocate sites for relatively big plots and ask developers to do more work". Whilst debates over planning gain have long been aired in northern cities, the institutionalisation of VP has shifted the balance of negotiations and priorities towards powerful market actors.

Our research found that VP also had significant effects on development planning politics in cities with strong market demand, such as London. Across the city, where political opposition to building on the green belt is strong and the land market is generally heated, the Mayor has identified numerous so-called Opportunity Areas to accommodate a large proportion of new housing delivery. Many of these areas are lower-value with 
poor existing transport and social infrastructure, requiring high-densities in order to make development viable. In evidence presented to the Examination in Public on the new London Plan (on 17 May 2019), Just Space - a pan-London network of community groups and activists - pointed to a real concern that 'in order to bring forward viable development on hard to develop brownfield sites which lack transport accessibility, high density is needed' (written evidence M92) which they suggest is leading to a "strong concentration of bad development in those places with high infrastructure costs" and housing that does not meet local housing need. Developers questioned why they are required to pay for infrastructure without there being any real certainty about it coming forward within a reasonable timescale. One housing provider suggested this was "taxing of development, without being hooked up to the certainty of infrastructure".

Outside the Opportunity Areas, outer London boroughs are concerned about the impact of the quantum of housing they are being required to deliver to meet the city's housing crisis without any committed funding so far for the transport infrastructure to support it. In one borough, a long-promised tram is key to unlocking housing development, but the Mayor has not identified funding to pay for it, thus relying on crosssubsidy from high-density development. One interviewee expressed concern that housing targets could not be met "without destroying the character of the borough" and that this was undermining their ambition to drive up quality, since, "we attract the bog-standard here".

Even in areas of extremely high domestic and international demand for housing, the pressures facing local authorities have been exacerbated by VP and it has become 
difficult to manage flows of investment. One inner London planner noted that whilst the symbolic anti-planning politics of the development and investment industries was relatively strong, the requirement to mobilise profitable opportunities meant that ultimately planners should be in a relatively strong position: "I've heard that in the developers' community they don't really like coming [here]. But they're lured here because of high development potential. And we can afford to be tough because they do want to come here". Even within such environments taking a 'tough' approach to market actors has proved extremely difficult. As the same interviewee noted, the formalisation of VP had "eroded away some of the plan-led system and allowed development plans to be over-ridden...there was a presumption that the market had to be the key driver in development and housing delivery" rather than the planning system. In a context where a range of private actors, some of them powerful overseas investors, are seeking planning permission, the local authority was trying to meet locally defined needs for affordable housing but was being undermined by market-driven appraisals and limited forms of value capture:

there was nothing really positive...yes we saw more development, and more council tax payments, more office schemes...but it created an environment where planning obligations were seen as being almost aspirational and could be negotiated away. And it became very difficult to fight.

Moreover, despite having strong development markets locally, it was noted that "really that should translate into the realisation of our development plan policies. But it was the market approach that was the actual issue here". 
Second, VP is limiting the capacity of state actors to introduce spatial and regeneration policy instruments, as it channels new and future investments away from areas with low market potential. Where interventions that were traditionally covered by state funding - sometimes termed 'gap funding' - are no longer available and projects are expected to develop sufficient income to be economically viable, then the range of possibilities open to public authorities and development agencies are increasingly limited. Respondents in northern cities have been particularly active in establishing schemes, including Joint Ventures and partnerships, in an effort to "lift costs off of the developers to get them to do projects". There is a sense that the public sector in these regions is doing what it takes to make it work for developers because "sometimes we all want the same outcome". It is not just in housebuilding that this approach is evident. In Newcastle, where commercial developers were being outbid by developers of student accommodation resulting in a shortage of Grade A office stock, the Council "had to intervene in the market to give enough confidence to private developers, landowners and financiers to invest in office blocks". On one scheme, they received a grant from the Local Enterprise Partnership for on-street works "to lift the cost off the developer to make it viable". In such cities, there is a real concern that they may return to a situation of population loss, since developable land is running out, green belt opportunities have been exploited and other sites are simply unviable to develop. The regeneration of former industrial sites has only happened on sites that have benefitted from long-term state investment, sometimes over decades. But with the introduction of market-driven planning,

Government policy doesn't provide long-term support so there will be long-term problems. The benefits of fifteen-year investments, like land remediation grants, 
are only coming through now, so in the future we won't be able to do developments on difficult sites.

It is not only northern cities that face these difficulties. One of the consequences of the gradual erosion of state ownership of housing is that VP will circumscribe the potential of public agencies to support area-based initiatives. As one outer London Borough interviewee noted,

It is on social estate regeneration programmes where there is going to be a real viability problem and a real crisis... if we wanted to intervene in the future we'd have to buy out all of the Leaseholders. This would make it unviable from the outset. So there is no mechanism for ever regenerating these estates as land values in outer London are not high enough to pay for it.

The result of these trends for public sector agencies in all contexts was the expansion of new forms of vulnerability and a reliance on fluctuating and unstable property markets. As an outer London planner noted in interview, "How would a viability report done in, say 2014, be valid now? They are only valid for a year or two and some of the predictions in our one are already wrong". Trying to plan for the long-term, whilst also co-ordinating different types of intervention (with different temporalities) has thus become increasingly difficult.

The consequences of reform are therefore particularly severe in places with low market potential. As with all types of market-driven intervention, it is likely that 
inequalities between and within cities and regions will therefore grow further. Efforts to protect greenbelts and prevent sprawl will come under growing pressure as development politics becomes skewed towards places and sites that have greater market potential. VP may therefore undermine the core objectives of both environmental sustainability planning and English urban policy, both of which encourage the redevelopment of brownfield sites in core urban areas. In areas of low development activity and market values, more challenging sites, such as old social housing estates and former industrial sites, have become labelled 'unviable' places, unsuited to new planning regimes and targets. In areas of London and South East England, with heated markets and land shortages, such sites are targeted explicitly for 'regeneration' but, in reality, are being comprehensively redeveloped in ways that differ markedly from local housing and employment needs and demands. Market-led VP is designed to attract private resources to places, communities, and neighbourhoods in need of new investment. However, early evidence shows that without strong state support and finance to overcome viability gaps and market limitations, such investments will not be forthcoming, thus circumscribing the capacity of planning policies to influence patterns of growth and development.

\section{Place-Making, commensurability and the diversity of local responses to viability-driven planning}

Across our case studies planners talked about the difficulties of commensurability or the process of translating qualitative local political demands into the quantitative abstractions associated with VP. Whatever the market conditions, it had become increasingly difficult to incorporate demands from citizens for quality design and affordable housing into the 
viability-driven need to combine growth with reasonable profit extraction. Those more qualitative aspects of local planning, including definitions of public interests and local needs, were being squeezed out by the reliance on quantitative market values and the socalled bottom line of profitable returns.

However, there was local variation in these processes, and we uncovered evidence of multiple forms of negotiation. One key variable is the role of elected local politicians and planning committees in understanding viability and in developing capacities to negotiate with private sector interests. As outlined in Table 1, our case studies are urban locations and have been governed predominantly by the leftist Labour and Liberal Democrat parties, who have tended to be proactive in pursuing development projects, both with market players and through state projects. In Newcastle, officers spoke of how Councillors struggled with the notion that they had "signed off" $15 \%$ affordable housing on a new residential development, yet the planners were later explaining that they could not secure any affordable housing because "it doesn't stack up" financially for the developer. Officers explained they had done training with planning committee members in order for them to "better understand" the viability process and that they "are getting to the point where committee now approve them, we're not saying they're happy with it, they do question it". Although politicians may be reluctant to concede on the basis that they consider their role to be 'guardians of the public interest' (Carmona et al., 2019), VP is leaving them with limited options.

The capacities and skills of officers to deal with VP varied between local authorities. In general, the authorities with greater development activity had better resourced planning departments with in-house skills and capacity to deal with the 
complexities of viability assessments and negotiate with developers. Some authorities had named viability officers or viability teams - these were a mix of planners who had reskilled and other property professionals, such as surveyors. Others relied heavily on, and worked closely with, their surveyor colleagues in strategic property and legal departments. In-house cross-departmental support was supplemented by the establishment of expert networks to support the public actors, including teams of lawyers and barristers that were on-call to support local planners and between whom embedded and established relationships of trust were evolving, thereby boosting the capacities of local authorities. As an interviewee noted, "often we need help with numbers on viability schemes and sometimes we need more support on strategic property - so lawyers have to be called in to help us as private companies have their own excellent lawyers. If we lose that capacity, then we have a problem". Even authorities with greater capacity outsourced work to consultants where in-house skills were lacking or when workloads were high, further adding to the private sector's input into local planning decision-making and reflecting broader trends towards the privatisation of planning knowledge (Parker et al., 2018). However, there is a limited pool of consultants and few who work exclusively for the public sector so that "the same consultants generally work for the private sector, it's a very niche group of people”.

The impact of austerity cuts on local authorities' capacities, even in fast-growing contexts such as central London, was evident and contributing to a reliance on consultants. Interviewees across the case studies noted that staffing and resources had been significantly cut-back and that this was limiting their ability to keep on top of fastchanging market conditions and multiple (and increasingly complex) planning applications. As one noted "austerity is making us all generalists reliant on external 
consultants". As they went on to note "we can no longer afford to bring in high quality consultants as they are too expensive...but the private sector can and does pay for the best consultants, the best lawyers, it all limits what we can do". One outer London interviewee noted that their team of planners had shrunk from 24 officers in 2008 to six in 2019, only three of whom worked in the field of planning policy. A planning officer from an inner London authority similarly commented that they had experienced a $70 \%$ reduction in their planning budget, and explained that "we could always do with more capacity, there were four of us [in the viability team], now there's just me" a situation compounded by the ongoing turnover of staff in central London as public agencies suffer from recruitment difficulties in large part brought on by the failure to produce an affordable housing supply: “we're also seeing more experienced officers are leaving London, it's just too expensive. At a time of life when they're moving out with their families... so we have a brain drain of experience".

The variation in housing markets across our local authority areas (see Table 1) was notable, ranging from over $£ 750,000$ for an average house in inner London to approximately $£ 150,000$ in Middlesbrough. In the outer London borough we reviewed, where average house prices are almost half that in inner London, it was reported that there was a strong continuity in planning officer teams and planning committees and that this was a factor in boosting local capacity. In the words of one interviewee "this is a relatively cheap place to live... so we have lots of home-grown talent and are different to other London authorities where there is a churn of staff'. This helped to generate an ‘institutional memory' of longer-term discussions that could be mobilised in negotiations: 
This means officers know what councillors are thinking and that local knowledge makes us more efficient. We know the history of big sites that have been knocking about for decades... we have spoken to every landowner and developer and they told whether their sites were viable or not.

There was no need for the Council to engage in costly exercises over viability projection when, it was claimed, negotiations took place in embedded social networks established locally over time. As another planner in the same authority noted, "if you've already spoken to the landowners and developers, that's a more reliable guide than relying on [abstract] typologies" used to inform viability assessments of the local plan. In the North East, there was a stability of planning staff and ease of recruitment in Newcastle compared to Middlesbrough, but this was put down to the greater success and prominence of Newcastle as a city and the reputation of its university and planning school. Our interviewee in Middlesbrough complained of losing good staff to Newcastle or the private sector, at the same time there was an awareness of Middlesbrough's relative strength compared to other authorities in the region, some of which have reportedly scrapped their planning departments altogether.

The patchy nature of capacity in planning departments was evident. In contrast to the broader (severe) decline in planning budgets across England, in some places there was evidence of greater investment in planning departments as local politicians believe that stronger planning regimes have the potential to generate significant returns. In Newcastle, the planning service was reportedly "now protected" and there was "a greater recognition of what planning does for house-building and what that does for Council Tax". Planning fees, paid by developers, were becoming a lucrative form of income and 
the Council had ring-fenced these incomes for the planning department for three to four years. This financial certainty, it was claimed, allowed planners to be more confident in their discussions with private actors, allowed negotiations over a longer time period, and helped to shift the form and character of such negotiations.

In the transition to VP we also found evidence that the requirement to translate qualitative demands and locally determined social infrastructure requirements into quantitative abstractions for viability testing had made it more difficult for local communities and lay people to have a voice. However, increased transparency and accountability was explicitly at the heart of the reform to the NPPF. As a civil servant at the MHCLG explained, "The intention was to empower local authorities and communities to hold developers to account by setting out clear expectations of what they want from a development, what the contributions would be and then the ability to hold developers to account when developments come forward". The 2018 reforms sought to achieve this by front-loading viability testing to the plan-making stage. However, the same civil servant acknowledged that this would only work "if you get good engagement and collaboration at the plan-making stage". When asked about the challenges of consulting with the community at the plan-making stage, one inner London borough acknowledged: "I think there's almost the expectation that it's mostly developers that are involved, but obviously the community need to be involved as well. Maybe we need to improve the mechanism a bit, to facilitate greater community involvement with viability and understanding it”. The lack of understanding of, and engagement with, viability reports at the plan-making stage is an almost inevitable outcome of a system that translates qualitative issues into abstract quantitative calculations whatever the local 
circumstances. There is also an issue of capacity limitations of both community groups and even smaller developers to engage at the plan-making stage.

In some places, there was evidence of a learning process on the part of local authorities and cross-boundary co-operation in an attempt to deploy 'better' and more robust quantitative models. One influential response has been for local authorities to work together to generate standardised approaches to VP. Within central London this approach has been translated into cross-borough and city-wide policies that seek to reempower planners vis-à-vis market actors. A London Protocol has been established in an attempt to standardise VP negotiations and convert them from the sphere of embedded local negotiations into more abstracted forms of best practice and prescribed notions of good value. By advocating the same narrative, planners in fast-growing areas felt that they were able to negotiate better deals with private actors and had received political support from both the London Mayor and local politicians in a context of austerity cuts “because we don't have money anymore and we need all this infrastructure, we need affordable housing. And we do have high development values in London, [so] it's only fair that we should capture some of it". The role for planners was to translate this broader political narrative into specific technical formats and calculations that could be used to extract large sums of finance from private actors. The shift to more standardised approaches has helped local planners to develop stronger negotiating positions and the London Protocol has been influential in guiding both the Mayor of London's and revised national guidance on viability, particularly around establishing common understandings of benchmark land values, and reinforcing the plan-led approach to make the market more subservient to the planning system. 
Similar techniques have been used in cities elsewhere. In Newcastle, for instance, the City Council has introduced formal guidance notes that set out some of the prerequisites for planning approvals. These state unambiguously that permissions will only be granted if they meet the "requirement to provide affordable housing" in which "applicants will be expected to meet the costs, as specified by the Council, associated with reviewing financial viability appraisals in advance". All submissions are subject to further "review by Chartered Surveyors in Strategic Property" and this is supplemented by the creation of a strategic property division that advises the planning committee through a "confidential report". Moreover, it is claimed that the Council has an embedded understanding of local market conditions and site potentials and that it will provide evidence of local viability market comparables rather than allowing descriptions and prescriptions to be set by private actors. The guidance sets out a clear road map for potential investors to follow, including a viability review that seeks to limit the potential of private actors to evade obligations through market changes so that "the onus is on the purchaser to make sufficient allowance for planning policy requirements and any other uncertainties".

In this section we have highlighted some of the geographical variables that are shaping the rolling-out of VP in different political contexts. We have shown how local actors are seeking to work with reforms and adapt them to local circumstances and priorities. There is evidence of learning at the local level and, in some cases, local authorities are being given additional resources to negotiate stronger planning gain requirements and to engage with a broader section of interests in establishing local political priorities. However, the findings of variation do not support the claims of authors such as Morphet and Clifford (2017) and Hackett (2017) for whom recent reforms 
can act as a resource for new types of innovative solutions and local government activities. The requirement to generate knowledge that is shaped by market criteria and abstractions, in a context of dwindling resources and capacities is having a limiting effect on the ability of local authorities to plan strategically.

\section{Conclusions}

This paper has used the example of the English planning system to explore the implications for development planning and spatial policy of the rolling out of recent reforms that prioritise financial viability concerns. Whilst planning gain and betterment instruments have constituted an important part of the post-war English planning system, and have been in existence since at least the 1930s (Askew, 2018), the re-tooling of these instruments through an explicitly viability-driven approach to planning through the National Planning Policy Framework challenges the very ethos of what the planning system is for and what it should achieve. Whereas it might be argued that the land use planning system emerged at the end of the 19th Century to address market failures and inherent inequalities, planning's role has become to support the market and facilitate returns to investors, working with rather than against market forces. This research has shown how VP exacerbates and reinforces a dependency on the market and private sector actors to deliver public benefit and magnifies the already existing inequalities between places. Local authorities and citizens face a growing degree of dependence on lucrative development on viable sites with potential for land value uplift, in order to fund broader infrastructure and affordable housing elsewhere. This is leading to an increasing political acceptance of development that might previously have been considered unacceptable, 
such as high density and tall buildings, and development on green belt sites. It is also undermining the perceived need for state funding to unlock or de-risk sites that are considered unviable and difficult to develop, exacerbating the issues of 'left-behind' places and regions. Planning's traditional role in compensating for market failures, promoting equitable development and supporting long-term regeneration is being eroded.

The outcome is a paradigm shift for what constitutes a coherent English urban and/or spatial policy, yet the negative impacts of this shift have yet to fully materialise. Development is only now coming forward on sites in disadvantaged regions that have benefited from past investment in the form of state grants. In the absence of alternative solutions, such development opportunities will soon dry up and the delivery of housing in these regions is likely to stagnate. In a context of widening inequalities between regions and nations of the UK (UK2070 Commission, 2020), the re-focusing of planning on viability and housing delivery raises the fundamental value-laden question of what planning is for.

Earlier analyses of planning gain mechanisms raised similar insights but were reflecting on (pre-austerity) contexts in which local authorities had greater capacities and resources and in which regional and spatial inequalities were less entrenched. Governments before 2010 also had a stronger commitment to redistributive spatial policy and/or the creation of regional and urban development agencies. A combination of austerity cuts, growing public sector indebtedness, centrally driven localism, and a (perceived) crisis of housing supply have combined to legitimate and justify the re-tooling of existing policy instruments and planning gain mechanisms. 
These findings are particularly pertinent as governments across Europe and elsewhere are increasingly looking to the market-led reform of local land value capture policy instruments to 'entrepreneurialise' local government practices and systems (see Gerber et al, 2018). Flexibilisation and market-led reforms also underpin the recent agendas of supra-national organisations, such as the World Bank (Amirtahmasebi et al., 2019). As we have shown, a reliance on market-led planning processes to deliver public benefit through land value capture focuses new investment in already successful places, compromises quality elsewhere, shortens the time horizons for planning and generates new vulnerabilities for planners. It suggests that other countries which may be looking with interest to England's experience of rolling out market-led planning should think carefully about the vulnerability of places and people under such a regime, and revisit the value of long-term, strategic and spatially nuanced urban policy approaches, and more equitable modes of planning that are less market-dependent.

Finally, we have revealed how the processes of abstraction and calculative practices associated with VP have led to a changing landscape of skills, roles and powerrelations within local government and between the public and private sectors. Public sector planners are required to work with the logic, and speak the language, of the private sector. Whereas the communicative planning turn at the end of the last century saw an emphasis on skills of communication, facilitation and consensus-building as core competencies within planning, there is now greater emphasis on a new forms of technocratic deliberation ( $c f$. Raco \& Savini, 2019) and the insertion of private sector priorities and expertise into the heart of planning governance, with an increasing reliance on consultants and other experts (in law, surveying etc) facilitating this transition. Under the regime of VP, the range of 'stakeholders' to be consulted are narrowed to a select few 
with property interests, who can advise on the viability of policies. The role of local communities in shaping planning outcomes, and that of councillors in representing the public interest, has been fundamentally weakened, as these actors' interests are side-lined by financial logics and abstractions, questionable and penetrable by only a select few experts. Thus, the trend towards a centralised localism, together with calculative modes of planning, has implications for traditional understandings of local politics and accountability in England and in planning systems elsewhere. It institutionalises the tensions and outcomes associated with all forms of commodification and has reinforced the need to develop a better understanding of the various forms of market-led planning as a mode of governance, with a stronger spatial awareness of the outcomes and challenges of centrally led reforms.

\section{Acknowledgments}

The authors would like to thank Mark Baker, Heather Campbell and four anonymous referees for their thoughtful and insightful comments on an earlier draft. The research for this paper was supported by the Economic and Social Research Council UK [Grant Number: ES/S015078] under the project 'WHIG What is Governed in Cities?: Residential investment landscapes and the governance and regulation of housing production'. Finally, we are grateful to our interviewees, and to John Tomaney for his contacts in the north east of England and his contributions to an earlier conference paper, presented at AESOP 2018.

\section{References}


Amirtahmasebi, R., Orloff, M., Wahba, S. \& Altman, A. (2019). Regenerating Urban Land: A Practitioners Guide to Leveraging Private Investment. World Bank Group. https://www.worldbank.org/en/topic/urbandevelopment/publication/regeneratingurban-land-a-practitioners-guide-to-leveraging-private-investment

Askew, J. (2018). A British perspective on added value capture: ups and downs during its history, in J. Gerber, T.Hartmann and T.Hengstermann (eds.) (2018), Instruments of land policy: Dealing with scarcity of land. Routledge.

Bailey, S. (1994). User charges for urban services, Urban Studies, 31(4/5), 745-65. https://doi.org/10.1080\%2F00420989420080661

Barca, F. (2009). Agenda for a Reformed Cohesion Policy; a place-based approach to meeting European Union challenges and expectations. European Commission.

Booth, P. (2003). Planning by Consent. Routledge.

Catney, P. \& Henneberry, J. (2019). The change in the political economy of land value capture in England, Town Planning Review, 90(4), 339-358.

\section{https://doi.org/10.3828/tpr.2019.24}

Campbell, H., Ellis, H., Henneberry, J. \& Gladwell, C. (2000). Planning obligations, planning practice, and land-use outcomes, Environment and Planning B, 27(5), 759-777. https://doi.org/10.1068\%2Fb2683

Campbell, H. \& Henneberry, J. (2005). Planning obligations, the market orientation of planning and planning professionalism, Journal of Property Research, 22(1), 37-

\section{9. https://doi.org/10.1080/09599910500411036}

Carmona, M., Gusseinova, A., \& Giordano, V. (2019). Councillors'Attitudes to Residential Design. London: Place Alliance. http://placealliance.org.uk/research/councillors-attitudes/ 
Christophers, B. (2014). Wild dragons in the city: Urban political economy, affordable housing development and the performative world-making of economic models. International Journal of Urban and Regional Research, 38(1), 79-97. https://doi.org/10.1111/1468-2427.12037

Coleman, C., Crosby, N. \& McAllister, P. (2012). Development appraisal in practice: some evidence from the planning system. Journal of Property Research, 30(2), 144-165. https://doi.org/10.1080/09599916.2012.750620

Cox, K. (1993). The local and the global in the new urban politics: A critical review, Environment and Planning D, 11(4), 443-448. https://doi.org/10.1068\%2Fd110433

Crook, T. (2020). Capturing Increases in Land Value. UK Collaborative Centre for Housing Evidence. https://housingevidence.ac.uk/publications/capturing-increasesin-land-value/

Crosby, N., McAllister, P. \& Wyatt, P. (2013). Fit for planning? An evaluation of the application of development viability appraisal models in the UK planning system. Environment and Planning B, 40(1), 3-22. https://doi.org/10.1068\%2Fb37181

Crosby, N., Lizieri, C. \& McAllister P. (2010). Means, motive and opportunity: Disentangling the effects of client influence of periodic performance measurement appraisals. Journal of Property Research, 27(2), 181-201. https://doi.org/10.1080/09599916.2010.499014

Crosby, N. \& Wyatt, P (2016). Financial viability appraisals for site-specific planning decisions in England. Environment and Planning C, 34(8), 1716-1733. https://doi.org/10.1177\%2F0263774X16636118

DCLG (Department of Communities and Local Government) (2012) National Planning Policy Framework. The Stationery Office

DCLG (2014) Viability planning practice guidance. The Stationery Office. 
Dunning, R., Lord, A., Keskin, B. \& Buck, M. (2019). Is there a relationship between planning culture and the value of planning gain? Evidence from England, Town Planning Review, 90(4), 453-471. https://doi.org/10.3828/tpr.2019.29

Déjean, F., Gond, J., \& Leca, B. (2004). Measuring the unmeasured: An institutional entrepreneur strategy in an emerging industry, Human Relations, 57(6), 741-764. https://doi.org/10.1177\%2F0018726704044954

Dunning, R., Lord, A., Keskin, B., \& Buck, M. (2019). Is there a relationship between planning culture and the value of planning gain? Evidence from England. Town Planning Review, 90(4), 453-471.

Edwards, C. \& Imrie, R. (2015). The Short Guide to Urban Policy. Policy Press. Eisenschitz, A. \& Gough, J. (1993). The Politics of Local Economic Policy: The Problems and Possibilities of Local Initiative. Palgrave.

Espeland, W., \& Stevens, M. (1998). Commensuration as a social process, Annual Review of Sociology, 24, 313-343. https://doi.org/10.1146/annurev.soc.24.1.313

Ferm, J. and Tomaney, J. (2018). Conclusions: Beyond Reflective and Deliberative Practice. In J. Ferm and J. Tomaney (eds.) Planning Practice: Critical Perspectives from the UK (pp.281-300). Routledge.

Gerber, J., Hartmann, T. \& Hengstermann, T. (eds.) (2018) .Instruments of land policy: Dealing with scarcity of land. Routledge.

Giamporcaro, S. \& Gond, J. (2016). Calculability as politics in the construction of markets: The case of Socially Responsible Investment in France, Organization Studies, 37(4), 465-495. https://doi.org/10.1177\%2F0170840615604498

Grayston, R. (2017). Slipping Through the Loophole: How Viability Assessments are Reducing Affordable Housing Supply in England. Shelter. 
Hackett, P. (2017). Delivering the Renaissance in Council Built Homes. The Smith Institute.

Hildreth, P. \& Bailey, D. (2014). Place-based economic development strategy in England: Filling the missing space, Local Economy, 29(4-5), 363-377. https://doi.org/10.1177\%2F0269094214535712

Healey, P., Purdue, M. \& Ennis, F. (1995). Negotiating Development: Rationales and Practice for Development Obligations and Planning Gain. E\&FN Spon.

House of Lords (2016). Building Better Places. Select committee on National Policy for the Built Environment, Report of Session 2015-16, 19 February. The Stationery Office.

Jenkins, S. (2020, 13 March). Johnson's egocentric budget gives him everything and local councils nothing, The Guardian https://www.theguardian.com/commentisfree/2020/mar/13/budget-johnsonegocentric-local-democracy

Jessop, B. (2003). Governance, governance failure, and meta-governance. Seminar paper presented at International Seminar on Policies, Governance and Innovation for Rural Areas, 21-23 November 2003, Università della Calabria. https://pdfs.semanticscholar.org/34b8/0d0068aaf63f653f737dc9ac0b7303572708.p df

McAllister, P. (2017). The calculative turn in land value capture, Land Use Policy, 63, 122-129. https://doi.org/10.1016/j.landusepol.2017.01.002

McGuinness, D., Greenhalgh, P., \& Grainter, P. (2018). Does one size fit all? Place neutral planning policy in England and its impact on housing land supplies and local development plans in NE England. Local Economy, 33(3), 329-346. https://doi.org/10.1177\%2F0269094218772974 
Miller, D. (2008). The uses of money, Geoforum, 39(3), 1122-1132.

https://doi.org/10.1016/j.geoforum.2006.03.009

MHCLG (Ministry of Housing, Communities and Local Government) (2019).

Viability: Planning Practice Guidance, 9 May 2019.

https://www.gov.uk/guidance/viability

MHCLG (2018a). Revised National Planning Policy Framework, 24 July. The Stationery Office

MHCLG (2018b). Supporting Housing Delivery through Developer contributions, March 2018. https://www.gov.uk/government/consultations/supporting-housingdelivery-through-developer-contributions

Morphet, J. \& Clifford, B. (2017). Local Authority Direct Provision of Housing. Royal Town Planning Institute.

National Audit Office (2019). Financial Sustainability of Local Authorities 2018. The Stationary Office.

Parker, G., Street, E. \& Wargent, M. (2018). The rise of the private sector in fragmentary planning in England, Planning Theory \& Practice, 19(5), 734-750. https://doi.org/10.1080/14649357.2018.1532529

Penny, J. (2017). Between coercion and consent: the politics of cooperative governance at a time of austerity localism in London, Urban Geography, 38(9), 1352-1373. https://doi.org/10.1080/02723638.2016.1235932

Pidd, H. \& Cocksedge, C. (2018, 6 March). How Manchester developers dodge affordable housing, The Guardian.

https://www.theguardian.com/cities/2018/mar/06/the-0-city-how-manchesterdevelopers-dodge-affordable-housing/ 
Raco, M. (2018). Private Consultants, Planning Reform and the Marketisation of Local Government Finance. In J. Ferm and J. Tomaney (eds) Planning Practice: Critical Perspectives from the UK (pp.123-137). Routledge.

Raco, M. \& Savini, E. (eds.) (2019). Planning and Knowledge: How New Forms of Technocracy are Shaping Contemporary Cities. Policy Press.

Savitch, H., Kantor, P. \& Vicari, S. (2002). Cities in the International Marketplace. Princeton University Press.

UK2070 Commission (2020). Make no little plans: Acting at scale for a fairer and stronger future. Final Report of the UK2070 Commission, February 2020. http://uk2070.org.uk/publications/

Van der Krabben, E. \& Jacobs, H. (2013). Public land development as a strategic tool for redevelopment: Reflections on the Dutch experience, Land Use Policy, 30(1), 774-783. https://doi.org/10.1016/j.landusepol.2012.06.002 